\title{
Community Environment and Education of Girls: The Case of Communities in Marsabit County, Kenya
}

\author{
Jafred Muyaka \\ Department of Foundations of Education, School of Education, University of Eldoret, Kenya
}

Copyright $\bigcirc 2018$ by authors, all rights reserved. Authors agree that this article remains permanently open access under the terms of the Creative Commons Attribution License 4.0 International License

\begin{abstract}
The study sought to investigate the role of the community in inhibiting girls' access and participation in formal education in Marsabit County-Kenya. As one of the marginalized counties in Kenya, the county had among the highest rate of illiteracy in Kenya with 68 per cent of residents with no formal education. The study involved a total of 128 informants, including school girls, boys, parents, and local leaders. The study utilized three main tools in data collection; interviews, focused group discussions and whole community mapping. The study found out that the selected four communities did not have adequate number of role models for girls; there were cases of teenage pregnancy, early marriages and practiced 'girl booking' that affected girls' participation in formal education. The study recommends tripartite efforts by the national government, county government of Marsabit County, and civil societies involved in advocacy of girls' education to particularly involve boys in their interventions to ensure that all girls access schools.
\end{abstract}

Keywords Girls, Community, Culture

\section{Introduction}

Commitment to provide Universal Primary Education (UPE) is a goal pursued by nations worldwide more-so in developing nations. Governments support provision of basic education especially primary education for it is positively correlated to economic growth and future opportunities for citizens' individual growth. According to Webster [15], primary education forms a strong foundation for future educational opportunities and lifelong skills. The primary education cycle is associated with skills and knowledge deemed crucial in contributing to economic development. For instance, the accumulated knowledge helps in reducing poverty and promoting gender equality in the world. Furthermore, primary education is now seen as a fundamental human right that frees children from ignorance and enhances their capacity to tackle poverty
[14]. Consequently, primary education is seen as a vital foundation for economic growth.

Universally, there exist legal and related policy frameworks that guarantee children a right to education. The 1948 United Nations Declaration of education as a human right saw enactment of international policy and convention that advocated for provision of basic education to both boys and girls across the world. The Convention on the Rights of the Child (CRC) enacted in the late 1980s and ratified in early 1990s reinforced rights of children beyond education. Consequently, individual states at different times of their history have aligned their constitutions and policy frameworks to provide universal and compulsory education to every child [15].

Whilst commitment to education is well documented and the zeal with which many countries including developing nations have pursued and ratified laws and policies in support of UPE is demonstrated, the targets of UPE remains elusive. In 2001, it was estimated that close to 115 million children of primary school going age were not in school and majority of them were girls [12]. Yet, education of girls is proved to have 'multiple effects' to the larger community. Girls' access to education is observed to promote family planning not only in the acquired knowledge but also in the fact that education delays the marry age of girls [15]. They end up with fewer children whose care and access to education is likely to be better. Furthermore, educated girls are more productive and enjoy better pay at workplace, easily participate in social, economic and political decision making. Therefore, denying children access to formal education is increasing their vulnerability to exploitation, all forms of abuse and diseases. Girls, more than boys are at increased risk of such exploitation.

The right to education involves three aspects namely: access, quality and respect to children's rights. The access to education as fundamental right calls for provision of an inclusive education that does not discriminate any child on the basis of gender, social economic status, race and disability. Similarly, quality looks at the kind of education that children access. The argument remains that education 
should serve for its purpose of instilling competences and a value system that helps children to fit into their respective societies. The emphasis is on provision of an education that builds one's potentials to participate fully in national development. Some of the indicators include the use of child centred teaching methodology, a broadened type of curriculum that is carefully structured, provision of infrastructure and a systematic monitoring of the education for improvement [11]. The last element to the right to education is the aspect of human rights which means children have basic rights which the process of education ought to guarantee and respect. It is envisaged that children access a quality education tailored within the universal human rights of children. Accordingly, school communities should ensure respect for every child by providing environments free from all forms of violence and abuse $[9,11]$.

In the World Summit meeting in 2000, United Nation member states committed their nations to reduce extreme poverty and set out a number of goals that were to be achieved by the year 2015 . These targets were commonly known as 'the Millennium Development Goals' (MDGs). The MDG goal number three set out to provide every child across the world a quality and compulsory primary education by the year 2015 [12]. However, by 2015, a number of nations had not achieved most of the goals. In recognition to this, the United Nation in 2012 met in Rio de Janeiro and set out an agenda to offer solutions to the world's urgent challenges relating to the environment, political and economic. These goals were termed Sustainable Development Goals (SDGs) that automatically replaced the MDGs. In total, there were 17 goals whose targets are to be achieved by the year 2030. Analysis of SDGs reveals that Goal four and Goal five have direct impact to education especially of girls. It seeks to ensure inclusive and equitable quality education and promote life-long opportunities for all while goal five calls for gender equality and empowering of all women and girls.

Kenya like many other countries has domesticated these international policy frameworks and aligned their legal documents in their efforts to provide UPE. The Constitution which was promulgated in 2010 guarantees a free and compulsory basic education for every child below the age of 18 years [9]. Then there is the Basic Education Act ([10] that called for access to education and also indicated that Kenyan children should access an education that guarantees quality, equity, and relevant to the new challenges of our time. Other facilitative legislation includes the Kenyan Children Act (2012) which protects children from all forms of negative practices within communities. Some of the practices include and not limited to early marriages, all forms of abuses, early pregnancies, negligence, Female Genital Mutilation (FGM), and sexual exploitation.

Kenya has had growth in the total number of primary schools and number of trained teachers as shown in Table 1
Table 1. Key Primary Education Statistics for Kenya, 2013-2015

\begin{tabular}{|c|c|c|c|}
\hline Year & $\mathbf{2 0 1 3}$ & $\mathbf{2 0 1 4}$ & $\mathbf{2 0 1 5}$ \\
\hline \# of Schools & 28,026 & 29,460 & 31,333 \\
\hline Total Enrolment & $9,857,600$ & $9,950,746$ & $10,090,759$ \\
\hline \# of trained Teachers & 199,686 & 200,697 & 210,991 \\
\hline
\end{tabular}

Source: The 2016 Kenya National Bureau of Statistics Statistical Abstract

The teacher to pupil ratio (TPR) as at 2015 was 1:48 which is an improvement of the 2013 TPR that stood at $1: 50$.

The 2014 Basic Education Statistical Booklet showed that, in 2014, Kenya had 1,292,675 out of school children [19]. There were more out of school girls (55.1\%) than boys (44.9\%). The disparities in access to basic education are huge with four arid and semi-arid counties of Mandera, Turkana, Marsabit and Garissa accounting for 34.2 percent of this out of school children [19].

The Kenya Certificate of Primary Education candidature for the period 2011-2014, showed more boys sitting for the national examinations as shown in Table 2.

Table 2. The Kenya Certificate of Primary Education Candidature, 2011-2014

\begin{tabular}{|c|c|c|c|c|}
\hline Gender & $\mathbf{2 0 1 1}$ & $\mathbf{2 0 1 2}$ & $\mathbf{2 0 1 3}$ & $\mathbf{2 0 1 4}$ \\
\hline Boys & 400,814 & 415,620 & 426,369 & 443,258 \\
\hline Girls & 375,400 & 396,310 & 413,390 & 437,228 \\
\hline Total & 776,214 & 811,930 & 839,759 & 880,486 \\
\hline
\end{tabular}

The candidature of girls over the period has grown faster as compared to boys (boys at $10.6 \%$ and girls at $16.5 \%$ ). However, over the same period there were slightly more boys than girls sitting for the national KCPE examinations.

Unfortunately, in Kenya, the presence of elaborate laws and enabling legislations on access to quality education has not recorded much success especially in marginalized communities. For instance, Ochieng reported that retrogressive cultural practices are still common in most marginalized Arid and Semi-Arid Lands (ASALs) Kenyan communities [7]. Regrettably, studies indicate that these cultural practices have negatively contributed to marginalization of girls' education [11].

Studies conducted in Kenya in early 1990s indicated that most ASAL communities did not provide the appropriate environment that would allow girls to access and remain in school to complete their education [13]. For instance, Wamahiu linked the socialization process in their communities to the girls' little confidence and aspirations in life [13]. The established community routines were no better and worked to marginalize girls more. Girls were exposed to more work at home compared to boys limiting their time to attend to their homework.

The other factor that impedes girls' access to education has been the rampant cases of early pregnancies and marriages within the communities. In most poverty stricken communities, girls are a source of income through traditional marriages that involves exchange of wealth [8]. 
World over, over two million births are associated with girls under the age of 15 with 90 percent of the two million already in some form of marriage [11]. In Kenya, the daily Nation of $20^{\text {th }}$ October 2012 revealed that 10 out of 100 pregnancies involved a girl between the ages of 15-19. Furthermore, 26 percent of Kenyan girls are married off before the age of 18 years. These marriages are not only against the Kenyan Laws but also endanger the lives of the involved teenagers. Already, the Kenyan Situational Analysis Report indicated that 70,000 adolescents in developing countries die each year from complications related to pregnancy and child birth [11].

High level of poverty in Kenya has been identified as among factors keeping girls out of school [12, 8]. In the year 2012, Plan International analysed the status of girls' education in Africa and indicated that poverty shaped parental decisions on how to use their scarce resources to secure their family. Unfortunately, girls were disadvantaged when such decisions involved boys as the latter were treated as first priorities [5]. On specific factors that affect girls' access and retention in formal education, they identified: gendered attitudes in the society; costs of education, transactional sex, early pregnancy, child marriage, child labour and distances to the schools [8]. All these identified factors have negative implications for their health, well-being and educational participation and outcomes.

This paper focused on the community environment and how it holistically inhibits or facilitate education of girls. The study was part of the larger qualitative study carried out in eight (8) counties under the Girl Education (GEC) Project Let All Girls Learn. These were two urban counties of Nairobi and Mombasa targeting slum schools and 6 arid and semi counties namely Marsabit County, Turkana County, Kwale County, Kilifi County, Samburu County and Tana River County. The project was undertaken under the financial support of the Department for International development (DfID) and implemented by a consortium of four independent organizations: Centre for British Teachers Trust (CfBT Trust), Ananda Marga Universal Relief Team (AMURT), Concern Worldwide and Girl Child Network, with Women Education Researchers of Kenya (WERK) responsible for research, monitoring and evaluation.

\section{Research Methodology}

The study was purely qualitative in nature in both data collection and analysis. Specifically, an ethnographic case study where the researchers spent one week in the four communities holding both formal and casual conversations with school going age girls, boys, parents, and community leaders including administrative leaders. It was through these conversations that the researcher got a holistic picture of the context in which girls lived and how the environment supported and/or inhibited their formal education.

\section{Sampling Sites and Study Locale}

\section{Study Locale}

The study was conducted in Marsabit County, one of the 47 counties in the Republic of Kenya. The County borders three counties: Wajir to the East, Turkana to the West and Isiolo to the South. The Northern part of the County borders Ethiopia

(http://www.kenya-information-guide.com/marsabit-count y.html).

According to the Kenya National Bureau of Statistics (KNBS) national Census conducted in 2009, Marsabit County had a population of 291,166 people [16]. There were more male $(52 \%)$ compared to the female $(48 \%)$ ). Of the population 40 per cent were Christians, 32 per cent Muslims while the remaining 28 per cent belonged to the other religions. The county is occupied by mainly five Cushitic and Nilotic ethnic communities. The Cushitic communities are Rendile, Gabbra and Borana and the Nilotic communities are Samburu and Turkana. It is reported to be among the driest areas in Kenya with 80 percent of the people known to be nomadic pastoralists. However, in recent times the communities have been involved in growing crops mainly millet, maize, kales and potatoes. The population involved in small scale farming is estimated to be about 10 per cent with 7 percent of residents actively involved in businesses and less than 3 per cent salaried people working with Non-Governmental Organizations and the Kenyan government. On average, the county has a household size of 4-6 members [15].

According to the County Government of Marsabit 2013-2017 Revised County Integrated Development Plan (Marsabit CIDP) almost a half (47\%) of the total population is made up of school going age children with a range of 0-14 years [3]. By 2013, the county had about 126 primary schools enrolling about 40,000 students with Teacher-Student Ratio of 1:54 way above the recommended national ratio of 1:40. The county has a high rate of illiteracy with 68 per cent of residents with no formal education, only 26 per cent with primary level education and only 6 per cent of the population with secondary education and above [3].

Primary school enrolment in Marsabit County between 2013 and 2015 was not steady. There was a sharp drop between 2014 and 2015 from 59,011 to 57,939 despite the increasing population of primary school age going children. In 2014, there were more boys $(52.5 \%)$ enrolled in Marsabit County than girls (47.5\%). The Marsabit County population projections by cohort and sex in 2014 indicated that there were 95,904 of primary school going age (5-14). In 2014, only 57,939 had enrolled [18] indicating that the county had 39.6 percent of out of school children with slightly more boys (51.9\%) than girls (48.1\%). Marsabit County in 2014 had a lower Gross Enrolment Ratio (GER) and Net Enrolment Ratio (NER) to the national figures at $79.5 \%$ and $65.8 \%$ respectively. The national GER and 
NER in the same year was $103.5 \%$ and $88.2 \%$ respectively

\section{Sampling Sites}

Schools Sites: The study was carried out in four (4) primary school communities. The structure of the settlements in Marsabit county especially in rural and peri-urban areas was in such a way that a primary school served a community or close communities. These were two (2) peri-urban school communities and two (2) rural school communities referred to as community $1 \mathrm{~A}, 1 \mathrm{~B}, 2 \mathrm{~A} \& 2 \mathrm{~B}$ respectively. The peri-urban school communities were approximately $50 \mathrm{KM}$ away from Marsabit town along the Moyale-Marsabit Highway. The community is considered peri-urban with daily life highly influenced by their closeness to Marsabit town. The population is made up of mainly Gabbra community but there is also presence of Borana community while the two rural schools were about $90 \mathrm{KM}$ away from Marsabit town, mainly Gabbra community. These communities were pastoralists with limited economic power.

Informants: The study involved 128 informants, 36 males including 24 boys and 92 females including 72 girls selected through purposive and snowballing sampling techniques. These were girls, boys, parents and/or guardians, community leaders mainly Chiefs, assistant chiefs, religious leaders and community based groups as shown in appendix 2.

\section{Data Collection}

The study utilised three key instruments to collect data. These were Focused Group Discussion (FGDs), Interviews and Community Observations as shown in appendix 1. Community observations included scrutiny of the available playgrounds, health facilities and social amenities in use in the community.

Data collection involved use of audio-recorders and cameras. Besides the recorded data, every researcher took notes as first basis of interrogating the collected data. The recorded data was later transcribed capturing the views and perspectives of the informants on the various themes that were under investigation. As the norm in qualitative studies, the researchers' views and perspectives were equally captured but separately from the interviewee's views.

\section{Data Analysis}

Data analysis was a continuous process right from data collection to the analysis of the transcribed data. There was preliminary analysis that took place during the fieldwork. This involved a continuous analysis of the interviews and observations carried out by the team of the researchers, a process that informed the subsequent interviews and observations. Additionally, there was a post-fieldwork conference involving all the researchers that had participated in the research. The post fieldwork conference formed the first stage of building consensus on the data that the teams had collected. In addition, this created an understanding of the researchers' perspectives on the various aspects of the research given that researchers were seen as tools for data collection. After this rigorous process, there was analysis of the collected and transcribed data using the analytical questions that had been derived from the broad study objectives. As part of enhancing validity, triangulation of the data from various sources was done and through this various themes developed to guide reporting of the findings.

\section{Ethical Considerations}

Ethical issues remain key in guiding research more-so when it involves children. In keeping in line with the established norms, the study made sure that informant gave consent, made assurance of confidentiality of the collected data, anonymity of the informants and assured informants of protection of their rights. In addition, participation of children involved seeking consent from their parents/guardians. When consent had been given by the parents, the researcher also sought the assent from the children. This explains the use of pseudonyms for the schools and subjects used in this study.

\section{The Findings}

\section{The Physical Environment and Amenities}

Physical Environment: The physical environment within the four communities could not empower both boys and girls socially, physically and mentally for formal education. Largely, the settlement pattern was nucleated with mostly temporal structures in the rural areas as shown in Figure 1 and more semi-permanent structures in the peri-urban communities.

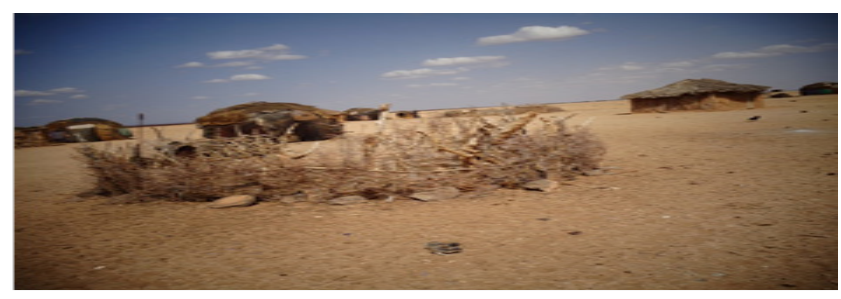

Figure 1. Settlement in Community 2A

The temporal structures signaled the nomadic nature of the residents that was common in the rural areas. In most cases, girls and boys would accompany their parents in search of pastures for their animals, moving from one village and establishing homes elsewhere. This disrupted education of girls and at the extremes led to drop out. Within the structures, facilities were minimal and mostly not comfortable for children's use to complete or even do 
their homework. In addition, three out of every five homes visited lacked a source of lighting. Those with a source of lightning attributed it to the efforts to the local NGOs mainly Concern Worldwide through their project entitled 'Let Girls Learn'. Overall, girls and boys still lacked a source of lighting which was necessary for them to complete the homework that they carried from their schools.

Health Facilities: The researchers looked at the status of the health facilities within the four communities. Studies show that healthy children access schools regularly enhancing completion rates and better learning outcomes [1]. There was a healthy facility in each of the four (4) communities. In community $2 \mathrm{~B}$, the research team visited the healthy facility (dispensary). On the day of the visit, the health clinical officer was present and indicated that the health status of most children was fairly good. However, the area experienced high rates of malnutrition among children.

Water Facilities: All these communities had some form of water supply that served the community. The peri-urban communities $1 \mathrm{~A}$ and $1 \mathrm{~B}$ had steady water supply than their rural counterparts. Through their own community initiatives, they had established functional boreholes operated as an income generating activity for their communities. Water was regular and managed by a few selected members. This was not the case in the rural communities $2 \mathrm{~A}$ and $2 \mathrm{~B}$. For instance, in community $2 \mathrm{~A}$, there were three boreholes, and one of them was as shown in Figure 2.

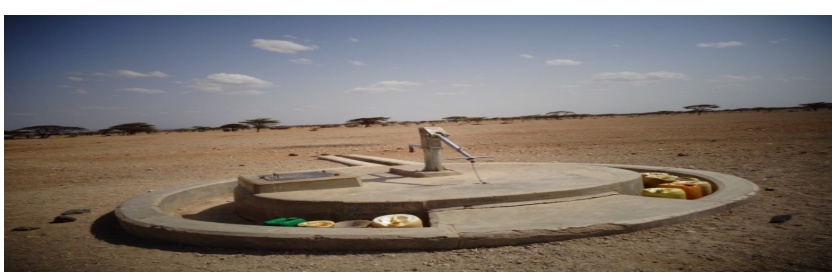

Figure 2. Borehole in Community 2B

However, the stay in the communities $2 \mathrm{~A} \& 2 \mathrm{~B}$ revealed that water supply was unsteady. In the four communities, the established normal trend was that girls fetched water and performed household chores than boys. Therefore, the irregular supply of water affected girls more and this further reduced their time for schoolwork. The photo in Figure 1 was taken during one of the evenings, the time most children collected water. There was no water and most of the girls who had come to fetch water were forced to go without and some opted to leave the containers at the borehole as shown in Figure 1. This finding presents the same picture as had been established by Wamahiu [12] about three decades ago where girls through socialization were exposed to more household chores than boys.

Holistic growth of children requires designated space for children to play in the communities. The study findings established that the communities that either did not have these spaces or those that had in the peri-urban areas were not safe for children play. The texture and state of the land made it difficult for creation of a smooth and safe playground. All these restricted co-curricular activities and development of psychomotor skills in both boys and girls.

\section{Community as a Source of Role Models and Inspiration}

The community remains the main source of inspirations and role models that school going children come in contact with first. Argued differently, girls' aspirations relate to the kind of the individuals they live and interact with daily in their communities. Interviews within the communities showed that children especially in the rural villages of Marsabit County lived with family members who had little or no formal education.

I have one brother and a sister. They have not gone to school' (Boy, who had dropped out but had re-enrolled back in school, 15th June 2015).

I stay with all my parents. I have three brothers and a sister. None has gone to school other than me (Enrolled Girl, 16th June 2015).

Community members with no formal education or limited education offer minimal academic support to girls and boys when left with homework. Furthermore, such communities have fewer role models at family levels and thus girls' understanding of career world is reduced considerably.

Even with the adverse environment in which girls lived, both the community members and girls interviewed expressed high aspirations and associated their future success to acquisition of education. Girls wished to pursue education through to universities and take up prestigious professions like medicine, teaching law and governance related studies. There was a strong conviction among girls that education was the only sure pathway out of poverty and many girls interviewed indicated that education is the avenue to uplift their families from abject poverty and poor living conditions.

In peri-urban communities, girls reported staying with educated family members. Some of the family members were pursuing university education thus providing a source of inspiration among girls. In one such interview, one of the girls noted thus:

I have three (3) sisters and one (1) brother. One of my sisters is in university but married; another one is in form four (4). My brother is in standard eight (8); and my other sister in class four (4) and class two (2) (Enrolled Girl, 12 ${ }^{\text {th }}$ June 2015).

Questions on aspirations and career choices show the level of awareness that pupils have to the available career choices. In community $2 \mathrm{~A}$ and $2 \mathrm{~B}$, both boys and girls showed limited knowledge on the available career opportunities open to them in future. All the interviewed 
girls and boys indicated that they would like to either be a teacher or a doctor. Overall, a career in teaching profession appeared to be the most popular among girls in rural communities of Marsabit County. This could be because teachers were the most available role models and professionals in these rural areas.

In community $1 \mathrm{~A} \& 1 \mathrm{~B}$, girls had high exposure to the various career choices. Some of the girls mentioned professions included taking a career in teaching, medicine, aviation, military and politics. In one of the interview the girl noted 'I want to go to college... [ ...to be a doctor or a teacher or a governor of the county'.

\section{Communities Perceptions on the Value of Education to Girls}

The current study investigated the community's views on girls' capability to excel in education. The process of socialization has been identified to perpetuate gender stereotypes that more often disadvantage girls. One of this has been the value of education to girls specifically when in direct competition to that of boys. Whereas earlier studies like Ochieng [6] had indicated in a similar study in Kilifi County Kenya that parents saw little value of girls' education, the interviews with parents in this Marsabit County painted a different picture. According to the interviews, education was beneficial to both boys and girls. While girls saw transformative potential of education to their future lives most of the community members support was purely from the expected financial and prestige associated with educated girls.

Through interviews and focused group discussions, girls were identified to be not only competitive but equally capable like boys. Overall, the community perceived education of girls as beneficial to the community and this attitudinal change was traced to the immediate benefits that the community has had from the few educated girls. Those girls accessing education had been competitive some performing well and getting admissions in good secondary schools in the country. Furthermore, there was a perception shared among community members that successful girls in the community have had more support to community initiatives than boys. This can be seen in the excerpts below:

When a girl child goes to school, they are good role models to this community and when these girls finish school and get a good job, they usually remember the family who are at the grass root. People actually say that when you take a girl child to school, it is better because you have educated the whole family of the whole community. (Community Leader (community B), 11th June 2015).

In Kalacha, there is a chief who is a woman, there is also a District Officer (DO) who is a woman and also in military and all of them is because of education. I have come from a wedding (yesterday) and the girl is in military and I am very happy. We are very happy of these girls... Community Leader 3, 2B 12th June 2015

Girls are even performing better than boys and getting to secondary schools. Also, they are more caring to us parents than our boys. You know boys marry and start their family and even forget about us. If you look around those families with girls who are successful are better off than those with boys. It is very common and this is encouraging us to take girls to school than when I went to school myself, girls were not many... Community Leader 6, 1A 17th June 2015.

Earlier studies had indicated that negative attitudes towards girls' education especially as related to their capabilities have and continue to hinder girls' access to education $[6,8,12]$. However, as established above, the findings indicate a change in the attitudes which if harnessed could improve the contribution of women to economic development.

Initiatives at community levels were cited for reduced number of few non-enrolled school going age children. According to the members interviewed, there existed small groups comprising of community members who partnered with the local administration to map out and enroll school going age children. These efforts were spearheaded by a local NGO based in Marsabit County 'Concern Worldwide'. The community voluntarily partnered with the government agencies and interested stakeholders in their enrolment campaigns. They identified the out of school children and engaged with their parents to enroll them in schools. Given that statistics indicate more girls are out of school than boys, such initiatives eventually benefited girls. Furthermore, some communities were actively involved in resource mobilization of their schools.

I will say the community here has supported education of girls fully. For instance, there are groups formed by Concern Worldwide to enroll both boys and girls in these villages. In every village we have a few leaders who organize meetings once like every month and with the help of a facilitator from Concern we strategize about our community problems among them education of our children. Now you see you cannot see so many un-enrolled children like before. Community Leader, 2, 2B 17th June 2015

Another example is Shantere Community Conversations (CCs) that send a delegation to the County government to request for teachers. The County government sends them 2 ECD teachers to help in the teaching. They also talked to the Cavellera Catholic Mission and the mission built a classroom for them. Community Leader, 5, 1A 17th June 2015

Involvement of Civil Society and both local and international NGOs in education of girls had earlier been reported by Benno when he indicated that most of the 
interventions had a component of girl education especially in enrolment drives and provision of boarding facilities [2].

The communities' involvement in school matters had tremendously improved. One notable change was the support that local schools received from their immediate communities, which ultimately improved the situation of a girl child education. There were more members from the community participating in school management either at individual levels or as committee members to school's Board of Management (BoM). This had improved the learning environment of the girls. In one such case, the community petitioned the Teacher Service Commission; the body responsible for hiring and managing teachers to take disciplinary measures against one of their misbehaving head teachers. The awareness and close scrutiny of education in their communities created a conducive learning environment both at community and school levels for both boys and girls.

I will give you a number of examples. At Hurr Hills a community started a process of disciplining a head teacher who was a drunkard. They wrote a letter to the Teachers Service Commission (TSC) and demanded that the head teacher be transferred. The matter was investigated and after TSC found the head teacher culpable he was transferred. Local NGO, 17th June 2015

I have seen more involvement of parents in school issues of their children. They are active in decision making both in BoMs as sometimes during meetings. I also receive complaints from parents about what happens in schools which was not the case when I started working as a chief here. There has been sensitization for parents to have a say in how to run their schools. This is good because even teachers know that in case of anything parents will ask. Local Community Leader 4 (2B), 20th June 2015

\section{Security and Safety of Children in the Communities}

The study analysed and reported on the security and safety levels of the children in the communities. The findings indicated that the community was fairly safe for both boys and girls. For instance, none of the girls and boys indicated violence emanating from community members other than physical abuse related to fighting amongst themselves. Overall, one in every 10 girls interviewed reported experiencing physical and verbal violence involving their colleagues. Other informants shared the same sentiments that the community remained safe for children particularly violence from elder members directed to both boys and girls. Partly, they attributed to the existing traditional leadership under their leader 'jalab' which had set out tough penalties involving all forms of violence. Jalab are found in every village occupied by the Gabbra community and reported to the community president referred to as ' $y a a$ '. Under 'yaa', children are highly protected especially from sexual and physical harm and repercussions for the perpetrators of violence to children were severe including extradition from the community.

Sometimes, you find children fighting especially when getting water or sometimes when we take animals in the fields for grazing. [....] mainly boys but also girls fight. (An Enrolled Girl, 18th June 2015)

This place, the place is safe, very safe. You know here the place is occupied by Gabbra alone and the other communities are not near here. Gabbra always love peace. Every time we have a ceremony leaders talk of peace. Our laws are severe if found guilty you are not taken to government but you are taken to Yaa (President of Gabbra) below Hurr hills. There you can be sent away from the community or asked to pay a fine like 3 camels, goats or just send away from the community completely. Around here there is Jalabu (village administrator) who takes care of the security. Everything is reported to him. Community Leader, 2 (2A) 14th June 2015

\section{Challenges Girls Faced at Community Level}

Even with the efforts noted in the communities, girls still encountered community related challenges in their efforts to access education. One of them was poverty that was so profound in the communities under study. Most of the community members depended on charity activities both by the NGOs and government to survive and very few involved in income generating activities. This is not strange given that Marsabit County Development Plan [3] estimated that only $10 \%$ of the population was involved in small scale farming, $7 \%$ in farming and a paltry $3 \%$ were involved in salaried jobs. Although poverty will naturally negatively affect both boys and girls, in these communities' girls were more disadvantaged with a common perception that the burden of educating a girl to the highest level was overwhelming compared to that of a boy.

There is lack of school fees. Parents can say that when the girl gets to secondary school she requires many things for upkeep so to avoid the expenses the girls are taken out of primary schools. []. The other example is the girl who had joined a secondary school in Nyeri (a secondary school in a far county) but was send away because of school fees. We were lucky that a woman in this community (Bokayo) mobilized and managed to get money and put her in the Centre of Excellence (North Horr Girls in Marsabit County). (Chairlady of a local CBO, 12th June 2015)

These findings corroborate well with the earlier studies that identified poverty as an impediment to access to education [3]. Studies like Plan International, [8] working in disadvantaged communities had even shown how poverty influences family decisions especially on use of 
extremely limited resources and in most cases in favor of boys.

The community experienced high levels of school drop-out. Girls in community 2A \& 2B were more affected than their counterparts in communities $1 \mathrm{~A} \& 1 \mathrm{~B}$. For every 10 girls interviewed in the rural communities, 6 of them reported to have dropped out of school at some point. The reasons cited for the high drop outs were as shown in Table 3:

Table 3. Factors that Lead to Drop Out in Community A

\begin{tabular}{|c|c|c|}
\hline No & $\begin{array}{c}\text { Reasons Mentioned by } \\
\text { Girls }\end{array}$ & $\begin{array}{c}\text { Reasons Mentioned by Other } \\
\text { Members }\end{array}$ \\
\hline 1 & Early marriage & Early marriage \\
\hline 2 & Taking care of animals & Taking care of animals \\
\hline 3 & Dislike schooling & Lack of uniforms \\
\hline 4 & Household Chores & Lack of fees \\
\hline 5 & House-helps/maids & Participation in cultural festivals \\
\hline 6 & & Indiscipline \\
\hline
\end{tabular}

In the eyes of the children and community members, two factors at community level remained a hindrance to girls' access to education. These were early marriage and looking after the animals. It is good to note that marriages still attract high financial gain to the girls' families and these communities were mainly pastoralists with high regard to their animals. Thus education had to compete with these highly regarded activities and unfortunately opportunity cost seemed to favour the former.

Poverty was identified by parents as another problem hindering girls' access to education while girls indicated that parents pulled them out of school for economic reasons (household chores and working as house maids for an income). Cases of teenage marriage were common in the four communities but more prevalent in the rural communities. These were partly supported by the community customs that institutionalized early marriages. The message was so strong that all the girls and boys interviewed observed that it will be too old for a girl of age 15 years to be in school. Ideally, 15-year-old girl, contrary to the Kenyan laws, was seen as adult enough to start a family.

The girl is too old to go to school at the age of 14 years because they get married at that age. And most of the body parts have developed and this they get mocked from fellow students, (Enrolled Girl 13th June 2015)

A lot of times for girls at 15 years they get married. Age 20 years is normally marriage age and should not be in school' (Re-Enrolled Boy 15th June 2015)

When asked if they had seen any of their colleagues drop out of school and get married, one of the girls noted; '...yes I have seen many like 5 girls. I remember one in 2013 she got married to Rage (neighbouring village) (Enrolled Girl, 13th June 2015).

Culturally, Gabbra community practiced a unique form of betrothing called 'booking'. The practice was unique given that a girl is engaged when she is as young as before she is born. This culture contributed to dropouts and early marriages. Girls and community leaders claimed that some parents would pull their girls from school when their suitors come for them. This was said to be common when the involved suitor was not enrolled and therefore education of a girl was directly linked to the boy or man that booked her. In worse circumstances, if the involved boy was not enrolled, then such a girl was never enrolled.

Parents are the reason why girls do not go to school because they book them for marriage too soon. Example: [Anne] who got booked to a man and is now waiting for the ceremony in Elbudha Village. (Enrolled Girl, 13th June 2015)

'Yes the girl was booked to a man and so she was not going to school. It's an agreement that the girl will marry someone. This is because the parents of the girls have assured him the girl. It also happens that the girl who has gone to school don't want to marry the uneducated boy. Also waiting for the girl to complete school is a problem. They prefer that the girl should not go to school.

\section{Community Leader, 1 (1B), 11th June 2015}

You know some boys have not gone to school. When girls get educated they refuse marrying those boys who have not gone to school [..] because those who have not gone to school herd animals in as far places like Forole and you see an educated girl will not fail to get an educated person for marriage. This creates conflict with involved families and to control this, families agree not to enroll such girls (Community Leader, 2 (2A) 14th June 2015

Men who were the main decision makers within their homes were accused of supporting teenage marriages. According to one of the administrative leader (chief), 'men are reluctant and still view their girls as a source of income'. Wealth as the reason for support of teenage marriage was further echoed by one of the community leader working closely with a local NGO when he noted;

'Yes you know the day your child gets married you get 3 camels, goats like 4, but there are so many things like clothes, tobacco. Some even pay as many as 11 goats. You know Gabbra really love camels so they release girls for wealth.'...

These findings are not new with a number of studies linking early marriages to the high levels of school drop outs among girls in different parts of the country [4].

The second main threat to education of both boys' and girls' was herding of livestock. However, in communities $1 \mathrm{~A} \& 1 \mathrm{~B}$, herding was minimal and affected mainly boys and not girls.

The boys are also in school but others are looking after the goats and camels but most of them are in schools. 
People here are nomadic and so if we have five boys, four go to school and one goes to look after the livestock... (Community Leader, 11th June 2015).

In community $2 \mathrm{~A} \& 2 \mathrm{~B}$ (rural areas), herding of livestock was mentioned by all categories of informants as affecting education of both girls and boys. For instance, out of the twenty (20) girls and boys who reported dropping out of school at one point in their school life, with exception of one boy, all indicated that they had been removed from school to look after their animals. Though the population was small to warrant a statistical significant, the fact that all these students reported having been removed from school to herd, is an enormous threat that livestock herding posed to education of both boys and girls. Further analysis of school going girls and boys who reported to have dropped out of school to herd revealed that the practice was common in lower classes.

Yes I dropped out in 2008 when I was in class 3. My parents had told me to take care of animals for two (2) years, Enrolled Girl, $13^{\text {th }}$ June 2015.

My parents pulled me out of school to take care of animals. []. I was in standard 2 and I stayed out of school for 1 year before I came back. [] One of my teachers complained to the chief who forced my parents to let me come back to school, Re-Enrolled Girl, 16 $^{\text {th }}$ June 2015.

There is lack of enough herdsmen so they drop to take care of animals. [Have you seen that with any of your friend] yes he dropped and is now back. He dropped in class 5 and came back after 1 year, Re-Enrolled Boy, $15^{\text {th }}$ June 2015.

Some they just refuse to go to school. Some parents remove them out of school to take care of goats and sometimes camels do not have someone to take care of them. You know there are so many reasons, Community Leader, 3 (1A) 14th June 2015

Girls don't go to school because they are forced to guard the animals in the adverse areas. They also help their mothers on domestic matters like fetching water and firewood. As parents move looking for pastures, they want children to be with them as they do not want the girls to be far away. Assistant Chief, (2A) 12th June 2015

\section{Conclusions}

The community environment became a major hindrance to girls' access to basic education. Girls' probability to access and remain in school to complete basic formal education was readily reduced as they faced both cultural and socio-economic challenges. There were high levels of poverty within the communities. Most parents and guardians did not have a source of income with proceeds from small scale pastoralism not adequate to feed their families, depending on charity especially in rural areas. Furthermore, cultural practices in the communities had adverse effects on girls' access to education. There were cases of early marriages where school going age girls were allowed to get married. In addition, through the practice of 'booking', girls attached to uneducated boys risked non enrolment or withdrawal from school. The other factors reported to keep girls out of school were herding, house chores and participation in traditional rituals. However, the safety and security within the sampled communities under the leadership of 'jalab' is a traditional model fused with local administrative structures worth emulating. Under the traditional leadership of 'jalab' girls were protected from physical violence, drugs, and sexual harassment. The punishment that the community leadership prescribed for any form of violence to girls was severe and this was reported to be the main reason for girls' relatively safer homes especially from sexual related forms of violence. The basic existing social amenities for recreation in the communities for both boys and girls were poor or not readily available. Playgrounds for children were rough and therefore not safe for use. In addition, water was not readily available and therefore girls had to make uncountable rounds of trips in search of water. Overall, the community, especially in the rural set up of Marsabit County, did not have adequate role models for their girls. Most of the girls did not have high aspirations as they had not been exposed to high achievers, mainly citing teachers as their role models.

\section{Recommendations}

1. The study established that early marriages involving school going age children was still common in the communities. In addition, 'booking' of girls was still in practice. Unfortunately, girls who were booked by non-enrolled boys rarely enrolled. There is need for the government and civil societies involved in advocacy of girls' education to change tact if more girls are to be enrolled. The efforts should equally target school going boys to ensure that their booked girls are allowed to access education.

2. The study established that the physical facilities within the community were disempowering reducing girls' preparedness to access education. The communities either did not have a playing ground or the one that was available was not safe for the girls. There is need to provide safer playing grounds to allow holistic growth of boys and girls in communities.

3. Water was not readily available especially in the two rural areas of the county. Girls' spent time fetching water and with irregular supply, they had 
to make several trips. This time would have been utilized in completing their homework and preparing for their school work.

\section{Appendix 1}

\begin{tabular}{|c|c|}
\multicolumn{2}{|c}{ Research Tools for the Study } \\
\hline $\begin{array}{c}\text { Whole } \\
\text { Community } \\
\text { Observations }\end{array}$ & $\begin{array}{c}\text { One in each of the } 4 \text { communities done continuously } \\
\text { for the one week researchers were in the community. } \\
\text { Targeted playgrounds, water facilities, health facilities } \\
\text { etc. }\end{array}$ \\
\hline Interviews & 64 interviews conducted \\
\hline FGDs & 4 FGDs in every of the community involving 64 people \\
\hline Total & In total involved 128 people. \\
\hline
\end{tabular}

\section{Appendix 2}

\begin{tabular}{|c|c|c|c|c|}
\hline Informants per Instrument \\
\begin{tabular}{|c|c|c|c|c|}
\hline Tool & Girls & Boys & Leaders & Totals \\
\hline Interviews & 24 & 24 & 16 & $\mathbf{6 4}$ \\
\hline $\begin{array}{c}\text { Focused Group } \\
\text { Discussions (FGDs) }\end{array}$ & 48 & 0 & 16 & $\mathbf{6 4}$ \\
\hline Community Observations & & & & \\
\hline Total & $\mathbf{7 2}$ & $\mathbf{2 4}$ & $\mathbf{3 2}$ & $\mathbf{1 2 8}$ \\
\hline
\end{tabular}
\end{tabular}

\section{REFERENCES}

[1] Action for Health Kids, Action for Healthy Kids. Retrieved from Action for Healthy Kids: Online Available from http://www.actionforhealthykids.org/storage/documents/pdf s/afhk_thelearningconnection_digitaledition.pdf on $8^{\text {th }}$ Septemeber, 2017.

[2] Benno, Jirm Elle, Assessment of Factors Affecting Female Teachers Participation in Management Position in Public Schools in North-Horr District, Marsabit County, Kenya (Thesis) Catholic University of East Africa, Kenya, 2012.

[3] County Government of Marsabit 2013-2017 Revised First County Integrated Development Plan (CIDP). Governement Press, Kenya, 2013.

[4] Kipkulei, C. B. Selected Factors Affecting Girls' Participation in Primary School Education in Barwessa Division of Baringo District, Kenya (Thesis). Egerton University, Kenya, 2008.

[5] Jewitt, S., \& Ryley, H. It's a girl thing: Menstruation, school attendance, spatial mobility and wider gender inequalities in Kenya. Elsevier, pp. 137-147, 2014.

[6] Ochieng, Rubai., Mandela. The Culture of Early Sex and Schooling of Girls in Kilifi County Kenya . British Journal of Education, 1-12, 2016.

[7] Ochieng, Rubai Mandela. Gender and HIV AIDS Education in the Multi-cultural Context of Schools at Kakuma Refugee Camp, Kenya. (Unpublished PhD Thesis), Kenyatta University, Kenya, 2010

[8] Plan International. Because I am a Girl: African Report 2012 Progress and Obstacles to Girls' Education in Africa. Plan International, Kenya, 2012.

[9] Republic of Kenya. The Proposed Constitution of Kenya. Government Press, Kenya, 2010b.

[10] Republic of Kenya. The Basic Education Act. Nairobi: Government Printer, Kenya, 2013.

[11] Republic of Kenya. Most at Risk Adolescent: Invisible Or Ignored? Summary Report of a Situational Analysis of Policy \& Health Care for Most at Risk Adolescents in Kenya, Government Printer, Kenya, 2016.

[12] UNICEF. Development Goals. Retrieved from: Achieve Universal Primary education: online available from https:/www.unicef.org/mdg/education.html, September 2017

[13] Wamahiu, Sheilah., Ochieng, Rubai., Limboro, Charity. \& Muyaka, Jafred. Education, Empowerment and Marginalisation: Do Schools Empower Girls? Case Studies of Selected Schools in Nairobi and Kilifi in Kenya. Unpublished GEC (WWW) Report. Nairobi: WERK, Kenya, 2014.

[14] Wamahiu, P. S., Opondo, A. F., \& Nyagah, G. Educational Situation of the Kenyan Girl Child. The Educational Research Network in Kenya (ERNIKE), 1992.

[15] Webster, T. Globalisation Of Education Policies: Extent Of External Influences On Contemporary Universal Primary Education Policies In Papua New Guinea, University of Papua New Guinea Press. New Guinea, 2000.

[16] Kenya National Bureau of Statistics, 2009 Kenya Population and Housing Census Analytical Reports, Government Printer, Kenya, 2009

[17] Kenya National Bureau of Statistics, 2016 Statistical Abstract, Government Printer, Kenya, 2016

[18] Kenya National Bureau of Statistics, 2015 Marsabit County Statistical Abstract, Government Printer, Kenya, 2015

[19] Ministry of Education Science and Technology (MoEST), The 2014 Basic Education Statistical Booklet, Government Printer, Kenya, 2015. 